\title{
Front Matter: Volume 9741
}

, "Front Matter: Volume 9741," Proc. SPIE 9741, High-Power Laser Materials Processing: Lasers, Beam Delivery, Diagnostics, and Applications V, 974101 (15 March 2016); doi: 10.1117/12.2239343

SPIE. Event: SPIE LASE, 2016, San Francisco, California, United States 


\title{
PROCEEDINGS OF SPIE
}

\section{High-Power Laser Materials Processing: Lasers, Beam Delivery, Diagnostics, and Applications V}

\author{
Friedhelm Dorsch \\ Stefan Kaierle \\ Editors
}

16-18 February 2016

San Francisco, California, United States

Sponsored and Published by

SPIE

Volume 9741 
The papers in this volume were part of the technical conference cited on the cover and title page. Papers were selected and subject to review by the editors and conference program committee. Some conference presentations may not be available for publication. Additional papers and presentation recordings may be available online in the SPIE Digital Library at SPIEDigitallibrary.org.

The papers reflect the work and thoughts of the authors and are published herein as submitted. The publisher is not responsible for the validity of the information or for any outcomes resulting from reliance thereon.

Please use the following format to cite material from these proceedings:

Author(s), "Title of Paper," in High-Power Laser Materials Processing: Lasers, Beam Delivery, Diagnostics, and Applications $V$, edited by Friedhelm Dorsch, Stefan Kaierle, Proceedings of SPIE Vol. 9741 (SPIE, Bellingham, WA, 2016) Six-digit Article CID Number.

ISSN: 0277-786X

ISSN: 1996-756X (electronic)

ISBN: 9781628419764

Published by

SPIE

P.O. Box 10, Bellingham, Washington $98227-0010$ USA

Telephone +1 3606763290 (Pacific Time) · Fax +1 3606471445

SPIE.org

Copyright (C) 2016, Society of Photo-Optical Instrumentation Engineers.

Copying of material in this book for internal or personal use, or for the internal or personal use of specific clients, beyond the fair use provisions granted by the U.S. Copyright Law is authorized by SPIE subject to payment of copying fees. The Transactional Reporting Service base fee for this volume is $\$ 18.00$ per article (or portion thereof), which should be paid directly to the Copyright Clearance Center (CCC), 222 Rosewood Drive, Danvers, MA 01923. Payment may also be made electronically through CCC Online at copyright.com. Other copying for republication, resale, advertising or promotion, or any form of systematic or multiple reproduction of any material in this book is prohibited except with permission in writing from the publisher. The CCC fee code is $0277-786 \mathrm{X} / 16 / \$ 18.00$.

Printed in the United States of America.

Publication of record for individual papers is online in the SPIE Digital Library.

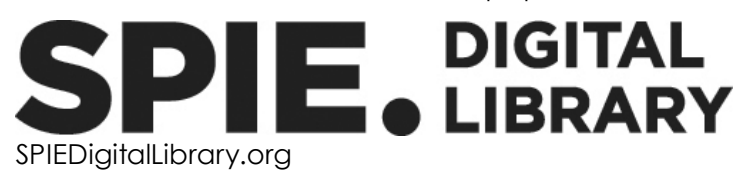

Paper Numbering: Proceedings of SPIE follow an e-First publication model. A unique citation identifier (CID) number is assigned to each article at the time of publication. Utilization of CIDs allows articles to be fully citable as soon as they are published online, and connects the same identifier to all online and print versions of the publication. SPIE uses a six-digit CID article numbering system structured as follows:

- The first four digits correspond to the SPIE volume number.

- The last two digits indicate publication order within the volume using a Base 36 numbering system employing both numerals and letters. These two-number sets start with 00, 01, 02, 03, 04, $05,06,07,08,09,0 A, 0 B \ldots$. OZ, followed by 10-1Z, 20-2Z, etc. The CID Number appears on each page of the manuscript. 


\title{
Contents
}

\author{
$\checkmark$ Authors \\ vii Conference Committee
}

SESSION $1 \quad$ BEAM SHAPING I: JOINT SESSION WITH CONFERENCES 9727 AND 9741

974102 Gauss to top-hat beam shaping with aspheres [9741-1]

SESSION 2 BEAM SHAPING II: JOINT SESSION WITH CONFERENCES 9727 AND 9741

974103 Industrial fiber beam delivery system for ultrafast lasers: applications and recent advances [9741-2]

974104 Monocrystalline CVD-diamond optics for high-power laser applications [9741-4]

$974105 \quad$ Computing specific intensity distributions for laser material processing by solving an inverse heat conduction problem [9741-5]

SESSION 3 CUTTING, DRILLING, STRUCTURING

974106 High precision and high aspect ratio laser drilling: challenges and solutions (Invited Paper) [9741-6]

974107 Can fiber laser improve high speed multi-pulse drilling of aeronautic alloy? [9741-7]

974108 Calibration of ultra high speed laser engraving processes by correlating influencing variables including correlative evaluation with SEM and CLSM [9741-8]

974109 Industrial grade fiber-coupled laser systems delivering ultrashort high-power pulses for micromachining [9741-9]

9741 OA The influence of scanning speed and number of scans on the properties of laser formed steel [9741-29]

SESSION 4 JOINING

9741 OB Simulation based analysis of laser beam brazing [9741-10]

9741 OC Laser-based gluing of diamond-tipped saw blades [9741-11]

9741 OD Laser welding of polymers: phenomenological model for a quick and reliable process quality estimation considering beam shape influences [9741-12] 
9741 OE A review article: The mechanical properties and the microstructural behaviour of laser metal deposited Ti-6Al-4V and TiC composite [9741-13]

SESSION 5 WELDING

9741 OG High-power CW and long-pulse lasers in the green wavelength regime for copper welding [9741-15]

$9741 \mathrm{OH} \quad$ Monitoring of solidification crack propagation mechanism in pulsed laser welding of 6082 aluminum [9741-16]

97410 Fiber laser welding of dual-phase galvanized sheet steel (DP590): traditional analysis and new quality assessment techniques [9741-17]

9741 0J Detection of transient reflections during laser beam welding of copper [9741-18]

9741 OK Transmission laser bonding of low melting eutectic alloys [9741-30]

\section{SESSION 6 BEAM MEASUREMENT}

$9741 \mathrm{OL} \quad$ Measuring laser power as a force: a new paradigm to accurately monitor optical power during laser-based machining operations [9741-19]

$97410 M \quad$ Localisation: characterisation of laser beam shape for materials processing using a new parameter [9741-20]

9741 ON Development of a non-contact diagnostic tool for high power lasers [9741-21]

9741 OP Absorption driven focus shift [9741-23]

\section{SESSION 7 PROCESS MONITORING}

$97410 Q \quad$ Comprehensive process monitoring for laser welding process optimization (Invited Paper) [9741-24]

9741 OR Inline monitoring of laser processing: new industrial results with the low coherence interferometry sensor approach [9741-25]

9741 OS Observation of melting conditions in selective laser melting of metals (SLM) [9741-26]

9741 OT Binary hologram based high speed zonal wavefront sensing with reduced estimation time [9741-27]

\section{POSTER SESSION}

9741 OU Analysis of weld seam uniformity through temperature distribution by spatially resolved detector elements in the wavelength range of $0.3 \mu \mathrm{m}$ to $5 \mu \mathrm{m}$ for the detection of structural changing heating and cooling processes [9741-28] 


\section{Authors}

Numbers in the index correspond to the last two digits of the six-digit citation identifier (CID) article numbering system used in Proceedings of SPIE. The first four digits reflect the volume number. Base 36 numbering is employed for the last two digits and indicates the order of articles within the volume. Numbers start with 00, 01, 02, 03, 04, 05, 06, 07, 08, 09, 0A, 0B...0Z, followed by 10-1Z, 20-2Z, etc.

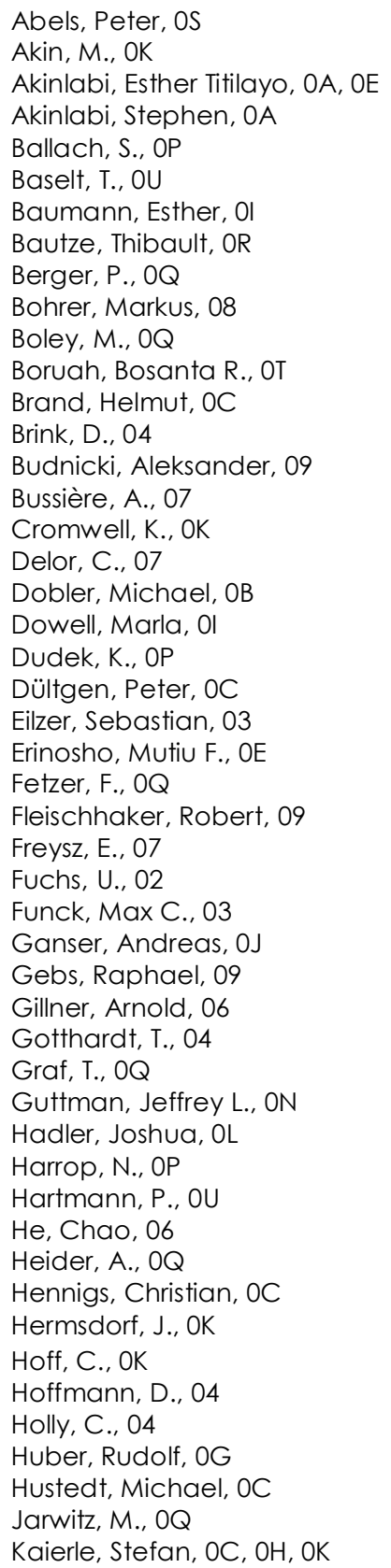

Kaiser, Elke, OG

Kazakov, Andrei, 01

Killi, Alexander, 09, 0G

Klausmann, Konrad, OG

Kleinbaver, Jochen, 09

Kling, R., 07

Kogel-Hollacher, Markus, OR

Kramer, R., OP

Lahdo, Rabi, OC

Lempe, B., OU

Liebl, Stefan, OJ

Loosen, Peter, 05

Loumena, C., 07

Maerten, O., OP

Maier, H. J., OK

Maschke, R., OU

McCauley, John, ON

Mielke, Michael, 09

Miller, Stephanie, 01

Möhl, A., 02

Moser, Rüdiger, OR

Nebel, C., 04

Nguyen, M., 07

Nirnberger, Robert, 08

Nutsch, Sebastian, 09

Overbuschmann, Johannes, 09

Overmeyer, L., OH, OK

Pathak, Biswajit, OT

Pfeif, Erik, Ol

Pricking, Sebastian, 09, 0G

Rudek, F., OU

Russek, Ulrich A., OD, OM

Sanusi, Kazeem Oladele, OA

Schmid, Daniel, OB

Schmidt, Michael, OB

Schmitz, Patrick, 0J

Schoenleber, Martin, OR

Scholl, Marcus, OD, OM

Simmons, Jed A., ON

Simonds, Brian, OL

Sowards, Jeffrey, OL

Sözbir, M. C., 04

Springer, André, OC

Stollenwerk, Jochen, 05

Stolzenburg, Christian, OG

Strebel, Matthias, OR

Stritt, P., OQ

Stuch, Julia, OD, OM

Sutter, Dirk H., 09 
Suttmann, $\mathrm{O}$., $\mathrm{OH}$

Thombansen, U., OS

Timpe, Nathalie F., OD, OM

Traub, M., 04

Uchtmann, Hermann, 06

Vaupel, Matthias, 08

Völl, Annika, 05

von Witzendorff, P., $\mathrm{OH}$

Weber, R., OQ

Wedel, Björn, 03

Weinberger, Bernhard, 08

Weller, D., OQ

Welp, Petra, 09

Wenzel, C., 04

Wickenhagen, S., 02

Widmann, C., 04

Wiethop, Philipp, OB

Williams, Paul, OL

Wloka, Richard, OC

Wolf, Martin, 09

Wolf, S., OP

Wurz, M. C., OK

Zaeh, Michael F., OJ

Zobel, Frank, OC

Proc. of SPIE Vol. $9741974101-6$

Downloaded From: https://www.spiedigitallibrary.org/conference-proceedings-of-spie on 26 Apr 2023 Terms of Use: https://www.spiedigitallibrary.org/terms-of-use 


\section{Conference Committee}

Symposium Chairs

Guido Hennig, Daetwyler Graphics AG (Switzerland)

Yongfeng Lu, University of Nebraska-Lincoln (United States)

Symposium Co-chairs

Reinhart Poprawe, Fraunhofer-Institut für Lasertechnik (Germany)

Koji Sugioka, RIKEN (Japan)

Program Track Chair

Bo Gu, Bos Photonics (United States)

Conference Chairs

Friedhelm Dorsch, TRUMPF Laser- und Systemtechnik GmbH (Germany)

Stefan Kaierle, Laser Zentrum Hannover e.V. (Germany)

Conference Program Committee

Bo Gu, Bos Photonics (United States)

Stefan W. Heinemann, TRUMPF Photonics (United States)

Klaus R. Kleine, Coherent, Inc. (United States)

Annett Klotzbach, Fraunhofer IWS Dresden (Germany)

Wolfgang Knapp, Cooperation Laser Franco-Allemande (France)

Lin Li, The University of Manchester (United Kingdom)

Silke Pflueger, DirectPhotonics, Inc. (United States)

Stephan Roth, BLZ Bayerisches Laserzentrum GmbH (Germany)

Leonardo D. Scintilla, Politecnico di Bari (ltaly)

Kunihiko Washio, Paradigm Laser Research Ltd. (Japan)

Session Chairs

1 Beam Shaping I: Joint Session with Conferences 9727 and 9741

Lutz Aschke, IVAM Microtechnology Network (Germany)

2 Beam Shaping II: Joint Session with Conferences 9727 and 9741

Friedhelm Dorsch, TRUMPF Laser- und Systemtechnik GmbH

(Germany)

3 Cutting, Drilling, Structuring

Wolfgang Knapp, Cooperation Laser Franco-Allemande (France) 
4 Joining

Klaus R. Kleine, Coherent, Inc. (United States)

5 Welding

Stefan W. Heinemann, TRUMPF Photonics (United States)

6 Beam Measurement

Kunihiko Washio, Paradigm Laser Research Ltd. (Japan)

7 Process Monitoring

Stefan Kaierle, Laser Zentrum Hannover e.V. (Germany) 